\title{
Analisis Fundamental dan Teknikal terhadap Harga Saham pada Perusahaan Utilitas dan Transportasi
}

\section{Christina ${ }^{1}$ \\ Fakultas Ekonomi \\ Universitas Prima Indonesia, Indonesia Universitas Prima Indonesia, Indonesia

\author{
Valentina Angrensia ${ }^{3}$ \\ Fakultas Ekonomi \\ Arie Pratania Putri ${ }^{4}$ \\ Fakultas Ekonomi \\ Universitas Prima Indonesia, Indonesia Universitas Prima Indonesia, Indonesia
}

\begin{abstract}
Surel : christina.ing43@gmail.com
\section{ABSTRAK}

Penelitian ini bertujuan untuk mengetahui apakah faktor fundamental dan teknikal memiliki pengaruh terhadap harga saham. Adapun faktor fundamental yang digunakan adalah current ratio, DER dan ROA sedangkan faktor teknikal yang digunakan adalah IHSG dan volume perdagangan. Populasi sebanyak 69 perusahaan sedangkan sampel yang dipilih sebanyak 18 perusahaan. Regresi yang digunakan adalah berganda karena variabel independen sebanyak 5 . Berdasarkan hasil uji secara parsial hanya DER dan ROA yang memiliki pengaruh signifikan secara positif terhadap harga saham sisanya tidak memiliki pengaruh terhadap harga saham. Secara serempak kelima variabel menunjukan pengaruh terhadap harga saham dengan hasil adjusted $\mathrm{r}$ square sebesar $29,1 \%$ dari variasi harga saham dijelaskan oleh variabel CR, DER, ROA, IHSG dan volume perdagangan dimana sisanya $70,9 \%$ dipengaruhi oleh variabel lainnya yaitu perputaran total aset, price earning ratio dan price book value.
\end{abstract}

Kata Kunci: Current Ratio; Debt to Equity Ratio; Harga Saham; Indeks Harga Saham Gabungan; Return On Asset; Volume Perdagangan.

\section{Analysis Fundamental and Technical of Stock Price in Utility and Transportation Company}

\begin{abstract}
The purpose of this research is to known if fundamental and technical analysis could affect the price of stock. Furthermore each of analysis have several factor to determine the stock price, as for fundamental analysis we will use current ratio, DER, and ROA while for the technical analysis we will use IHSG and trading volume. From the population of 69 company we pick 18 sample that suit the analysis, for the regression it will use multiply 5 because of the independent variabel. According to the partial research, there are only two factor that have significant impact to the price of stock, it is DER And ROA, as for the rest of the factor it don't really affect the price. Simultaneously the five variabel shown the effect to the stock price according to result of adjused $r$ square amount of $29.1 \%$. From the variation of stock price according to the variabel such as CR, DER, ROA. IHSG and trading volume, while the rest $70.9 \%$ affected by other factor such as company asset turnover, price earning ratio and price book value.
\end{abstract}

Keywords: $\quad$ Current Ratio; Debt to Equity Ratio; IDX Composite; Return On Asset; Stock Price; Trading Volume.

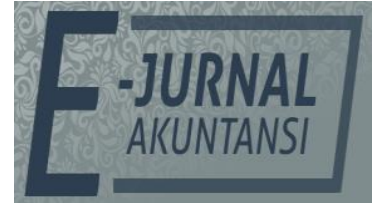

e-ISSN 2302-8556

Vol. 31 No. 2

Denpasar, Februari 2021

Hal. 499-512

DOI:

10.24843/EJA.2021.v31.i02.p19

PENGUTIPAN:

Christina., Halim, S., Angresia, V. \& Putri, A.P. (2021). Analisis Fundamental dan Teknikal Terhadap Harga Saham pada Perusahaan Utilitas dan Transportasi. E-Jurnal Akuntansi, 31(2), 499-512

RIWAYAT ARTIKEL: Artikel Masuk: 9 Desember 2020 Artikel Diterima: 20 Februari 2021

Artikel dapat diakses : https://ojs.unud.ac.id/index.php/Akuntansi/index 


\section{PENDAHULUAN}

Perkembangan dunia bisnis saat ini mengalami persaingan yang semakin ketat. Kondisi ini menyebabkan perusahaan dituntut untuk meningkatkan kinerjanya agar dapat bertahan dalam jangka panjang. Untuk menghadapi persaingan yang ketat, perusahaan harus berbenah diri dengan menerapkan manajemen modern dan strategi bersaing (Ilmiyono, 2019). Harga saham yang tinggi adalah salah satu strategi bersaing yang menunjukkan value yang lebih bagi perusahaan yang memilikinya. Harga saham merupakan salah satu indikator keberhasilan manajemen perusahaan, jika harga saham suatu perusahaan selalu meningkat, investor atau calon investor menganggap perusahan berhasil mengelola bisnisnya. Keyakinan investor atau calon investor ini sangat menguntungkan bagi emiten, karena semakin banyak masyarakat yang mempercayai emiten tersebut sehingga kemauan berinvestasi pada emiten semakin kuat (Astuty, 2017).

Tanda ikut serta permodalan dalam suatu organisasi perseroan terbatas ditunjukkan pada selembar kepemilikan atas saham. Bagi perusahaan penerbitnya, saham akan meningkatkan nilai ekuitas perusahaan karena dapat memanfaatkannya sebagai sarana untuk memperoleh pendanaan. Ada dua alternatif penting dalam keputusan pendanaan antara lain menggunakan modal sendiri atau memperoleh hutang dalam menjalankan usahanya. Sumber pembiayaan dari modal sendiri dapat dilakukan melalui penerbitan saham, sedangkan sumber pendanaan utang dilakukan dengan menerbitkan obligasi, right issue atau utang ke bank. Kedua alternatif pendanaan ini masing-masing memiliki perbedaan satu sama lain. Dalam memenuhi kebutuhan keuangan perusahaan, tentunya akan menimbulkan biaya, baik yang terlihat maupun tidak. Seiring dengan keputusan pendanaan bagi perusahaan dalam bentuk saham, keberadaan pasar modal saat ini sangat diperlukan sebagai wadah untuk berinvestasi dalam mendapatkan deviden bagi mereka yang menjadi pemilik atau pemegang saham. Selain berinvestasi saham, investor juga dapat melakukan investasi pada beberapa instrumen yang dapat mengurangi risiko (Purnamawati, 2016).

Dari sudut pandang investor, disarankan agar memiliki pengetahuan dan kesadaran potensial tentang pergerakan pasar dan determinan dari pergerakan tersebut. Para ahli mengaitkan beberapa faktor internal dan faktor eksternal sebagai faktor yang mempengaruhi harga saham. Faktor internal utama adalah kinerja perusahaan, tata kelola, aset dan posisi likuiditas, dividen dan pendapatan. Faktor eksternal meliputi peraturan pemerintah, siklus bisnis, sikap investor, kondisi pasar, bencana alam dan ketidakpastian politik seperti pemogokan, blokade, dan lain sebagainya (Alam et al., 2016). Investor diharapkan mendasarkan keputusan investasinya pada informasi kinerja keuangan perusahaan. Informasi keuangan tersebut selanjutnya akan digunakan untuk menganalisis perubahan harga sahamnya yaitu faktor fundamental dan teknikal.

Faktor fundamental ini berhubungan dengan keseluruhan ekonomi atau industri atau perusahaan tertentu. Pemilihan sebuah investasi akan dimulai dengan analisis fundamental. Analisis fundamental meneliti lingkungan ekonomi, kinerja industri dan kinerja perusahaan sebelum membuat keputusan 
investasi (Suresh, 2013). Analisis fundamental menggunakan data masa depan dan sekarang untuk memperkirakan saham wajar pasar dan untuk memprediksi nilai masa depan. Biasanya dimulai dengan menganalisis file lingkungan ekonomi makro, menganalisis sektor dan kemudian laporan keuangan secara berurutan untuk menentukan nilai riil perusahaan. Tujuan dari analisis tidak hanya untuk menemukan sebuah perusahaan yang sukses; tujuannya adalah untuk menemukan perusahaan yang bernilai lebih dari yang perkiraan investor. Analisis fundamental bukan jaminan bahwa investor akan merealisasikan keuntungan tinggi atas saham, tetapi pasti memiliki peran penting dalam mencapai tujuan ini (Baresa et al., 2013).

Sedangkan Analisis teknis adalah salah satu metode paling umum yang digunakan investor untuk membuat keputusan investasi yang menggunakan pengetahuan latar belakang harga dan data terkait untuk meramalkan harga di masa depan (Ghobadi \& Abdolbaghi, 2014). Ketika investor memutuskan untuk berinvestasi di pasar modal, perlu mengetahui semua variabel yang mempengaruhi investasi mereka dan apakah investasi ini menguntungkan atau tidak. Tahun yang lalu para investor menggunakan "Strategi buy dan hold" berdasarkan analisis fundamental untuk menganalisis investasi. Teknis analisis menggunakan harga masa lalu dan statistik terkait dengan perkiraan investasi. teknis analisis dalam perbandingan untuk analisis fundamental memiliki beberapa Keuntungan dan Kekurangan. Salah satu keuntungannya adalah menemukan harga perdagangan terbaik yang tidak mungkin ditemukan itu dengan strategi buy and hold. Negara Nepal membuktikan bahwa aksesibilitas likuiditas, analisis fundamental dan analisis teknis merangsang kinerja pasar sahamnya. Lebih pentingnya, pasar saham telah terbukti merespon secara signifikan terhadap perubahan dividen dan suku bunga (Thapa, 2019).

Kondisi dan kinerja suatu perusahaan dapat mempengaruhi harga sahamnya. Minat investor akan semakin meningkat jika kinerja perusahaan semakin baik, sehingga terjadi kenaikan harga saham. Current Rasio (CR) yang lebih besar dapat menunjukkan kemampuan perusahaan dalam memberikan dividen yang dijanjikan terhadap investor dapat dipercaya kemampuannya. Sehingga dengan demikian semakin banyak investor yang berminat ataupun tertarik pada saham perusahaan sehingga akhirnya mempengaruhi harga secara positif.

Jika dilihat dari analisis leverage, Debt to Equity Ratio (DER) meningkat relatif kurang bagus, karena perusahaan akan mengalami kebangkrutan jika terjadi likuidasi. Terdapat probability harga saham perusahaan akan turun, jika DER perusahaan tinggi ketika perusahaan tersebut mendapatkan laba perusahaan mengutamakan laba tersebut digunakan untuk membayar hutang dari pada memberikan dividen pada pemegang saham. Kondisi ini kurang memicu minat investor pada saham yang dipilih dan akhirnya mempengaruhi harga saham secara negatif.

Semakin tinggi Return On Asset (ROA) maka dapat dilihat bahwa semakin baik pula produktivitas aset suatu perusahaan dalam memperoleh untung secara bersih. Maka memberikan dampak yang sangat baik untuk harga saham perusahaan karena investor akan menjadikan perusahaan tersebut sebagai tempat dimana menanamkan sahamnya, karena 
tingkat return akan semakin tinggi. Rasio ini akan mempengaruhi positif pada harga saham perusahaan Penelitian ini dilakukan pada perusahaan sektor utilitas dan transportasi karena dengan banyaknya wilayah kepulauan di Indonesia, maka sarana transportasi dianggap aspek penting bagi infrastruktur di Indonesia, namun ini menghabiskan anggaran Negara yang diakibatkan karena kebutuhan yang sangat besar akan pembangunan sektor tersebut. Menurut Badan Koordinasi Penanaman Modal pada awal Agustus 2019 sektor ini menjadi sektor yang terunggul. Namun terdapat ketidaksesuaian antara teori yang ada dengan data pada perusahaan.

Menurut Rambe et al., (2015) current ratio (CR) merupakan ukuran yang paling umum dari kelancaran (solvency) jangka pendek, karena rasio tersebut menunjukkan seberapa jauh tagihan para kreditor jangka pendek bisa ditutup oleh aktiva yang secara kasar bisa berubah menjadi kas dalam jangka waktu yang sama dengan tagihan tersebut. Pengaruh CR terhadap harga Samsuar \& Akramunnas, (2017) yaitu Semakin baiknya rasio current maka rasionya menunjukan semakin liquid suatu perusahaan. Kondisi ini menyebabkan harga sahamnya positif. Jadi, CR diasumsikan memiliki hubungan yang searah pada peningkatan harga sahamnya, artinya ketika CR meningkat, harga sahamnya juga bergerak mengikuti. Menurut Arifannisa \& Nugraha, (2017) CR yang rendah dapat menimbulkan keraguanpara investor untuk menginvestasikan modalnya ke perusahaan.Yang dikaranekan perusahaan dinilai tidak mempunyai kemampuan untukmelunasi kewajiban- kewajiban lancarnya, sehingga dapat menurunkan permintaan saham sektor tersebut. Hipotesis dari penelitian ini adalah sebagai berikut.

$\mathrm{H}_{1}$ : current ratio berpengaruh positif terhadap harga saham pada perusahaan utilitas dan transportasi.

Menurut Jusuf, (2016) secara umum dapat dikatakan bahwa semakin tinggi rasio ini maka risiko kreditor (termasuk bank) semakin besar karena DER yang tinggi berarti semakin rendah tingkat keamanan dana yang ditempatkan oleh kreditor dalam bisnis tersebut. Pengaruh DER Terhadap Harga Saham Samsuar \& Akramunnas, (2017) semakin kecil DER, maka makin tinggi harga karena utang perusahaan sedikit dan investor semakin tertarik untuk membeli saham suatu perusahaan. Menurut Arifannisa \& Nugraha, (2017) apabila suatu perusahaan memiliki DER yang kecil ataupun rendah maka menunjukan kemungkinan bahwa harga saham perusahaan akan tinggi karena apabila perusahaan mendapat laba, perusahaan akan cenderung mengutamakan pembagian deviden untuk para investor. Peningkatan DER tidak akan mempengaruhi kemampuan perusahaan dalam membagikan deviden kepada pemegang saham. Hal ini menunjukkan peningkatan rasio hutang tidak akan membuat perusahaan mengurangi pendapatan yang akan diterima oleh pemegang saham. Perusahaan akan membayar dividen lebih banyak ketika laba perusahaan naik dan pertumbuhan perusahaan stabil, artinya ketika perusahaan memperoleh keuntungan yang besar, sedangkan kebutuhan dana untuk membiayai pertumbuhan aset rendah, maka perusahaan dapat meningkatkan pembayaran deviden kepada pemegang saham (Fitri et al., 2016). DER adalah perhitungan lain yang menentukan entitas kemampuan membayar utang jangka panjang." DER mencerminkan kemampuan perusahaan untuk membayar atau 
memenuhi kewajibannya dengan modal sendiri. DER menunjukkan hubungan antara jumlah pinjaman yang diberikan oleh pemilik perusahaan (Gibson, 2009). CR dan DER tidak berpengaruh signifikan terhadap hasil investasi (Komala \& Nugroho, 2013). Hipotesis kedua pada penelitian ini yaitu sebagai berikut.

$\mathrm{H}_{2}$ : DER berpengaruh negatif terhadap harga saham pada perusahaan utilitas dan transportasi.

Semakin besar ROA, berarti semakin efisien penggunaan aktiva perusahaan atau dengan kata lain dengan jumlah aktiva yang sama bias dihasilkan laba yang lebih besar, dan sebaliknya (Sudana, 2015). Pengaruh ROA terhadap harga saham dalam perkataan dari Samsuar \& Akramunnas, (2017) harga saham di pengaruhi oleh ROA karena semakin tinggi ROA suatu perusahaan maka menunjukan bahwa perusahaan tersebut menggunakan aktiva perusahaannya secara efektif untuk mengghasilkan laba bersih. Hal ini dapat menimbulkan daya tarik investor untuk berinvestasi. Menurut Alipudin \& Oktaviani, (2016) semakin tinggi rasio dari ROA maka produktivitas aktiva dalam mendapatkan laba bersih yang semakin bagus. hal ini yang membuat daya tarik perusahaan kepada para investor semakin bagus dan hal ini membuat perusahaan tersebut disukai oleh para investor karena tingkat pengembaliannya besar. Dalam Sunday \& Small, (2012) ROA menyatakan pendapatan bersih yang diperoleh perusahaan sebagai persentase dari total aset yang tersedia untuk digunakan oleh perusahaan tersebut. ROA menunjukkan bahwa perusahaan dengan jumlah aset yang lebih tinggi harus dapat memperoleh tingkat pendapatan yang lebih tinggi. ROA mengukur kemampuan manajemen untuk memperoleh laba atas sumber daya (aset) perusahaan. Jumlah pendapatan yang digunakan dalam perhitungan ini diperoleh sebelum dikurangi biaya bunga, karena bunga adalah pengembalian kepada kreditor atas sumber daya yang mereka sediakan untuk perusahaan. ROA dihitung dengan membagi laba bersih ditambah beban bunga dengan investasi rata-rata perusahaan dalam aset selama tahun tersebut. Dalam sebuah penelitian bursa efek Saudi (Tawadul) menunjukkan bahwa terdapat hubungan positf yang signifikan antara ROA dan CR di perusahaan Arab Saudi (Rehman et al., 2015). Hipotesis selanjutnya dari penelitian ini adalah sebagai berikut.

$\mathrm{H}_{3}$ : $\mathrm{CR}$ berpengaruh positif terhadap harga saham pada perusahaan utilitas dan transportasi.

Indeks harga saham merupakan faktor signifikan awal yang mempengaruhi pengambilan keputusan keuangan investor. Karena itulah memprediksi pergerakan yang tepat dari indeks harga saham sangat dipertimbangkan (Moein Aldin et al., 2012). Indeks Harga Saham Gabungan (IHSG) atau biasa juga disebut dengan Composite Share Price Index yaitu salah satu Indeks Pasar Saham yang ditetapkan untuk mengukur kinerja gabungan seluruh saham yang tercatat di Bursa Efek Indonesia (Harsono \& Wonokinasih, 2018). Naik atau turunnya IHSG mempengaruhi harga saham. Jika Indeks Harga Saham Gabungan mengalami peningkatan maka mengakibatkan kondisi perekonomian negara dan kondisi investasi dalam keadaan bagus (Samsuar \& Akramunnas, 2017). Hipotesis selanjutnya dari penelitian ini adalah sebagai berikut. 
$\mathrm{H}_{4}$ : Indeks Harga Saham Gabungan berpengaruh positif terhadap harga saham pada perusahaan utilitas dan transportasi.

Faktor selanjutnya yang mempengaruhi harga saham yaitu Volume Perdagangan.Volume perdagangan menggambarkan seberapa banyak lembar saham yang diperjual belikan dalam satu periode waktu tertentu. Semakin sedikit lembar saham yang diperjual belikan maka mengakibatkan semakin menurunnya juga harga saham (Arifannisa \& Nugraha, 2017). Hal ini menunjukkan optimisme pasar terhadap sebuah saham. Dalam kutipan dari Nasution et al., (2016) volume perdagangan saham itu adalah sarana yang dipergunakan untuk mengetahui apakah individual atau investor menilai laporan secara informatif, dengan arti dapatkah informasi tersebut digunakan untuk mengambil keputusan perdagangan dalam kondisi umum. Volume dagang di pasar modal berguna sebagai informasi yang sangat berguna bagi para investor. Volume perdagangan melonjak berdasarkan budaya dan kelembagaan nasional lingkungan masing-masing negara. Investor cenderung berdagang dalam masyarakat yang tingkat kepercayaan dan individualismenya lebih tinggi daripada tingkat kepercayaan yang lebih rendah untuk menghindari ketidakpastian. Investor juga lebih bersedia berdagang di negara-negara kaya, yang juga memiliki perlindungan hak hukum yang lebih kuat, sistem tata kelola yang lebih baik, dan perjudian yang lebih besar (Chiah \& Zhong, 2020). Hipotesis selanjutnya dari penelitian ini adalah sebagai berikut.

$\mathrm{H}_{5}$ : Volume perdagangan berpengaruh positif terhadap harga saham pada perusahaan utilitas dan transportasi.

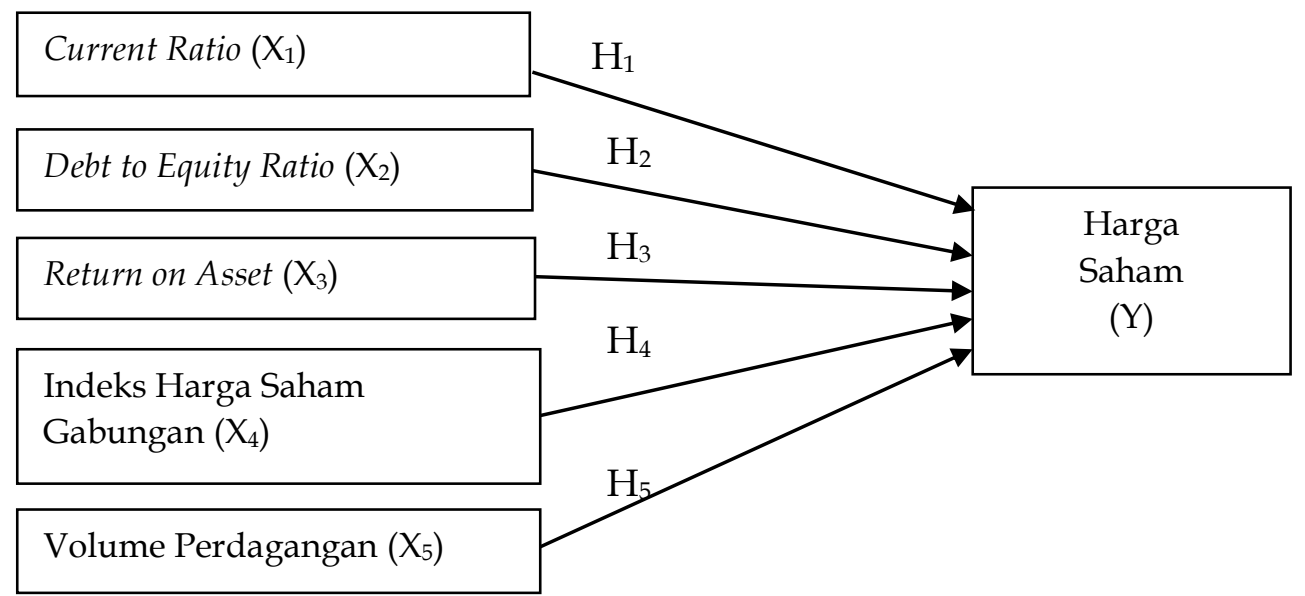

Gambar 1. Model Penelitian

Sumber: Data Penelitian, 2020

\section{METODE PENELITIAN}

Studi ini dilakukan pada perusahaan utilitas dan transportasi yang terdaftar pada Bursa Efek Indonesia/BEI dengan website www.idx.co.id. Adapun metode penelitian yang kami gunakan dalam melakukan penelitian ini yaitu metode penelitian deskriptif kuantitatif karena penelitian ini menggunakan data kuantitatif maka untuk menggambarkan data yang telah diolah maka akan di sajikan dalam bentuk deskriptif. Data yang dikumpulkan menggunakan teknik dokumentasi yaitu mengumpulkan laporan keuangan 
tahunan perusahaan utilitas dan transportasi yang sudah diaudit dan diunduh dari website resmi www.idx.co.id serta mengumpulkan literatur yang berkaitan dengan variabel dipilih. Jenis data dalam penelitian ini adalah data kuantitatif yang menggunakan sumber sekunder dari laporan keuangan sektor yang diteliti yang dipublikasikan di situs BEI.

Populasi : 69 perusahaan yaitu semua perusahaan utilitas dan transportasi yang terdaftar di Bursa Efek Indonesia sejak tahun 2016 sampai dengan tahun 2019. Sampel dipilih berdasarkan purposive sampling, berdasarkan pertimbangan 1 . Perusahaan utilitas dan transportasi yang sudah go publik selama tahun 2016-2019. 2. Perusahaan utilitas dan transportasi yang sahamnya tercatat di BEI dari tahun 2016 - 2019 dan memiliki data sesuai variabel penelitian. 3. Perusahaan utilitas dan transportasi yang memperoleh laba bersih selama tahun 2016-2019 berturut-turut.

Uji Asumsi Klasik yang digunakan untuk penelitian initerdiri dari uji normalitas, heteroskedastisitas, autokorelasi, multikolinearitas, dan dimana jika terpenuhi maka dapat dikatakan bahwa model regresi tersebut best linear unbiased estimation. Pengujian hipotesis pada penelitian ini untuk mengetahui apakah variabel independen berhubungan secara parsial maupun simultan terhadap variabel dependen menggunakan uji $\mathrm{F}$ dan uji t. Adapun model regresi yang digunakan adalah analisis regresi berganda dengan rumus sebagai berikut.

$Y=a+b_{1} X_{1}+b_{2} X_{2}+b_{3} X_{3}+b_{4} X_{4}+b_{5} X_{5}+\varepsilon$

Keterangan:

$$
\begin{array}{ll}
\mathrm{Y} & =\text { Harga Saham } \\
\mathrm{a} & =\text { constanta } \\
\mathrm{X} 1 & =\text { Current Ratio } \\
\mathrm{X} 2 & =\text { DER } \\
\mathrm{X} 3 & =\text { ROA } \\
\mathrm{X} 4 & =\text { Indeks Harga Saham Gabungan } \\
\mathrm{X} 5 & =\text { Volume Perdagangan } \\
\mathrm{b} 1, \ldots ., \mathrm{b} 5 & =\text { Koefisienregresi } \\
\varepsilon & =\text { Variabel pengganggu }
\end{array}
$$

Berdasarkan hasil dari analisis regresi diamati Koefisien Determinasi, Uji F dan Uji t.

\section{HASIL DAN PEMBAHASAN}

Banyaknya data yang diuji berjumlah 72 data yang diambil dari 18 sampel perusahaan kali 4 tahun periode penelitian. Hasil uji statistik deskriptif uji data ini yaitu : (1) Nilai minimum Current Ratio PT. Jasa Marga, Tbk tahun 2019 adalah 0,280. Nilai maksimum sebesar 6,683 dihasilkan oleh PT. Cikarang Listrindo, Tbk dan nilai rata-rata sebesar 1,379. (2) Nilai minimum Debt to Equity Ratio PT. Rukun Raharja, Tbk tahun 2017 adalah 0,252. Nilai maksimum sebesar 13,543 dihasilkan oleh PT. Tower Bersama Infrastructure, Tbk di tahun 2016 dan nilai rata-rata sebesar 1,704. (3) Nilai minimum Return on Asset PT. Buana Listya Tama, Tbk tahun 2016 adalah 0,002. Nilai maksimum sebesar 0,165 dihasilkan PT. Telekomunikasi Indonesia, Tbk di tahun 2017 dan nilai ratarata sebesar 0,056. (4) Nilai minimum IHSG sebesar 5297 di tahun 2016, 
maksimumnya di tahun 2017 sebesar 6356 dan nilai rata-rata sebesar 6036,75. (5) Nilai minimum volume perdagangan yaitu 0,0000. Nilai maksimum sebesar 0,263 dihasilkan oleh PT. Telekomunikasi Indonesia di tahun 2016 dan nilai ratarata sebesar 0,016. (6) Nilai minimum harga saham PT. Pelayaran Tempuran Emas tahun 2019 sebesar Rp 102,-, nilai maksimum sebesar Rp 6.425,- dihasilkan oleh PT. Tower Bersama Infrastructure di tahun 2017 dan nilai rata rata sebesar Rp 1.560,49.-

Table 1. Hasil Statistik Deskriptif

\begin{tabular}{lrrrrr}
\hline & $\mathrm{N}$ & Minimum & Maximum & \multicolumn{1}{c}{ Mean } & Std. Deviation \\
\hline CR & 72 &, 280 & 6,683 & 1,379 & 1,268 \\
DER & 72 &, 252 & 13,543 & 1,704 & 1,907 \\
ROA & 72 &, 002 &, 165 &, 056 &, 036 \\
IHSG & 72 & 5297,00 & 6356,00 & 6036,750 & 434,063 \\
Volume Perdagangan & 72 &, 000 &, 263 &, 0165 &, 0403 \\
Harga Saham & 72 & 102 & 6425 & 1560,49 & 1643,083 \\
Valid N (listwise) & 72 & & & & \\
\hline
\end{tabular}

Sumber: Data Penelitian, 2020

Berdasarkan hasil uji Kolmogorov Smirnov nilai asymp. sig diperoleh 0,084 yang mana lebih besar dari 0,05 maka data penelitian ini memiliki distribusi secara normal.

Tabel 2. Uji Normal Kolmogorov Smirnov

\begin{tabular}{llr}
\hline & & Unstandardized Residual \\
\hline $\mathrm{N}$ & Mean & 72 \\
Normal Parametersa,b & Std. Deviation &, 000 \\
& Absolute & 1333,750 \\
Most Extreme Differences & Positive &, 148 \\
& Negative &, 148 \\
Kolmogorov-Smirnov Z & &,- 094 \\
Asymp. Sig. (2-tailed) & & 1,259 \\
\hline
\end{tabular}

Sumber: Data Penelitian, 2020

Uji ini menunjukkan jika antar variabel tidak memiliki korelasi karena telah memenuhi syarat yaitu besarnya nilai tolerance sudah melebihi 0,10 dan besarnya nilai VIF tidak melebihi 10 sehingga hasil uji ini tidak terjadi mutikolinearitas.

Tabel 3. Uji Multikolinearitas

\begin{tabular}{llrr}
\hline Model & & \multicolumn{2}{c}{ Collinearity Statistics } \\
\cline { 3 - 4 } & & \multicolumn{2}{c}{ Tolerance } \\
\hline \multirow{4}{*}{1} & CR &, 930 & 1,076 \\
& DER &, 917 & 1,091 \\
& ROA &, 908 & 1,102 \\
& IHSG &, 962 & 1,039 \\
& Volume Perdagangan &, 896 & 1,116 \\
\hline
\end{tabular}

Sumber: Data Penelitian, 2020

Untuk $\mathrm{k}(\operatorname{var} \mathrm{X})=5$ dan $\mathrm{n}$ (jumlah data $)=72$ maka :

$\mathrm{dL}=1,4732 \quad 4-\mathrm{dL}=2,5268 \mathrm{dU}=1,7688 \quad 4-\mathrm{dU}=2,2312$ 
Sehingga hasil uji Durbin Watson memenuhi kriteria kelima yaitu dU $<\mathrm{d}<4-$ $\mathrm{dL}$ atau 1,7688 < 2,355<2,5268 yang kami simpulkan tidak ada gejala autokorelasi positif maupun negatif di data penelitian ini.

\section{Tabel 4. Uji DurbinWatson}

\begin{tabular}{lll}
\hline Model & Durbin-Watson & \\
\hline 1 & & 2,355 \\
\hline
\end{tabular}

Sumber: Data Penelitian, 2020

Uji ini dilihat dari nilai signifikan yang dihasilkan yang dilihat pada kolom signifikansi, dimana jika nilai signifikan melebihi dari 0,05 maka uji ini terbebas dari masalah heteroskedastisitas, dengan melihat hasil uji spearmans rho pada data penelitian dapat disimpulkan jika data yang diuji tidak memiliki gejala heteroskedastisitas.

Tabel 5. Uji Spearman's rho

\begin{tabular}{|c|c|c|c|c|c|c|}
\hline & & CR & DER & $\mathrm{ROA}$ & IHSG & $\begin{array}{c}\text { Volume } \\
\text { Perdagangan }\end{array}$ \\
\hline Unstandardized & $\begin{array}{l}\text { Correlation } \\
\text { Coefficient }\end{array}$ & 193 &,- 137 &,- 102 & ,002 & 103 \\
\hline \multirow[t]{2}{*}{ Residual } & Sig. (2-tailed) & 104 & ,252 & ,395 & ,984 & ,389 \\
\hline & $N$ & 72 & 72 & 72 & 72 & 72 \\
\hline
\end{tabular}

Sumber: Data Penelitian, 2020

Hasil uji persaman, dapat diberi penjelasan sebagai berikut : (1) Constanta a menunjukkan angka -1101,242 dimana apabila variabel independen Current Ratio, Debt to Equity Ratio, ROA, IHSG dan Volume Perdagangan tetap atau bernilai 0 maka harga saham sebesar-1101,242. (2) Setiap kenaikan Current Ratio sebesar 1 satuan akan menyebabkan penurunan harga saham sebesar 86,031 satuan. (3) Setiap kenaikan DER sebesar 1 satuan akan menyebabkan peningkatan harga saham sebesar 402,223 satuan. (4) Setiap kenaikan ROA sebesar1 satuan akan menyebabkan peningkatan harga saham sebesar 16699,184 satuan. (5) Setiap IHSG naik sebesar 1 satuan akan menyebabkan peningkatan harga sahamnya sebesar 0,186 satuan. (6) Setiap kenaikan volume perdagangan sebesar 1 satuan akan menyebabkan peningkatan harga sahamnya sebesar 2070,140 satuan. Hasil uji ini dibuat dalam bentuk persamaan sebagai berikut.

Harga Saham $=-1104,242-86,031 \mathrm{CR}+402,223$ DER $+16699,184$ ROA + 0,186 IHSG + 2070,140 Volume Perdagangan

Tabel 6. Persamaan Regresi Berganda

\begin{tabular}{|c|c|c|c|}
\hline \multicolumn{2}{|c|}{ Model } & \multicolumn{2}{|c|}{ Unstandardized Coefficients } \\
\hline & & $B$ & Std. Error \\
\hline \multirow{6}{*}{1} & (Constant) & $-1104,242$ & 2391,965 \\
\hline & CR & $-86,031$ & 134,265 \\
\hline & DER & 402,223 & 89,880 \\
\hline & $\mathrm{ROA}$ & 16699,184 & 4686,865 \\
\hline & IHSG & ,186 &, 386 \\
\hline & Volume Perdagangan & 2070,140 & 4292,840 \\
\hline
\end{tabular}

Sumber: Data Penelitian, 2020

Besarnya nilai Adjusted $\mathrm{R}$ Square berdasarkan hasil uji koefisien determinasi adalah sebesar 0,291 yang artinya sebesar $29,1 \%$ dari variasi harga saham yang dapat dijelaskan oleh variabel independen yaitu Current 
Ratio, DER, ROA, IHSG dan volume perdagangan dimana sisanya sebesar 70,9\% dipengaruhi oleh variabel lain misalnya perputaran total aset, price earning ratio dan price book value.

Tabel 7. Hasil Uji Koefisien Determinasi

\begin{tabular}{|c|c|c|c|c|c|}
\hline Model & $\mathrm{R}$ & R Square & Adjusted R Square & Std. E & sttmate \\
\hline 1 & $584^{a}$ & 341 & 291 & & 83,349 \\
\hline \multirow{6}{*}{\multicolumn{6}{|c|}{$\begin{array}{l}\text { Sumber: Data Penelitian, } 2020 \\
\quad \text { Nilai F tabel untuk df } 1 \text { (5) dan df } 2 \text { (66) adalah sebesar } 2,35 \text {. Dengan } \\
\text { demikian F hitung }(6,833)>\mathrm{F} \text { tabel } 2,35 \text { dan nilai signifikan } 0,000<0,05 \text { berarti } \\
\text { Ha diterima dan Ho ditolak sehingga secara simultan hasil penelitian ini CR, } \\
\text { DER, ROA, IHSG dan volume perdagangan mempengaruhi harga saham secara } \\
\text { signifikan. } \\
\text { Tabel 8. Uji F. }\end{array}$}} \\
\hline & & & & & \\
\hline & & & & & \\
\hline & & & & & \\
\hline & & & & & \\
\hline & & & & & \\
\hline \multirow[t]{2}{*}{ Model } & & & $\mathrm{df}$ & $\mathrm{F}$ & Sig. \\
\hline & Regre & & 5 & 6,833 &, $000^{\mathrm{b}}$ \\
\hline & Resid & & 66 & & \\
\hline & Total & & 71 & & \\
\hline
\end{tabular}

Sumber: Data Penelitian, 2020

Tabel pada probabilitas 0,05 (2 arah) dan df 66 adalah sebesar 1,99656. Maka hasil uji t pada penelitian ini dapat dijelaskan per variabel bahwa Current Ratio memiliki nilai -thitung>-ttabel atau -0,641>-1,99656 dan nilai signifikan 0,524 > 0,05 maka berarti Ho dterima atau Ha ditolak artinya current Ratio tidak berpengaruh terhadap harga saham. Variabel DER memiliki nilai $t$ hitung $>$ $\mathrm{t}$ tabel atau 4,475>1,99656 dan nilai signifikan 0,000 < 0,05 maka Ha kami terima atau Ho ditolak yang berarti DER berpengaruh signifikan secara positif terhadap harga saham. Variabel ROA memiliki nilai $\mathrm{t}$ hitung $>\mathrm{t}$ tabel atau 3,563>1,99656 dan nilai signifikan 0,001 < 0,05 maka Ha kami terima atau Ho ditolak yang berarti ROA berpengaruh signifikan secara positif terhadap harga saham. Variabel IHSG memiliki $t$ hitung $<\mathrm{t}$ tabel atau $0,483<1,99656$ dan nilai signifikan 0,631 > 0,05 maka Ho diterima atau Ha ditolak yang berarti IHSG tidak mempengaruhi harga saham. Variabel volume perdagangan memiliki $t$ hitung $<\mathrm{t}$ tabel atau 0,482<1,99656 dan nilai signifikan 0,631 > 0,05 maka Ho kami terima atau Ha ditolak yang berarti volume perdagangan tidak mempengaruhi harga saham.

Tabel 9. Uji $t$

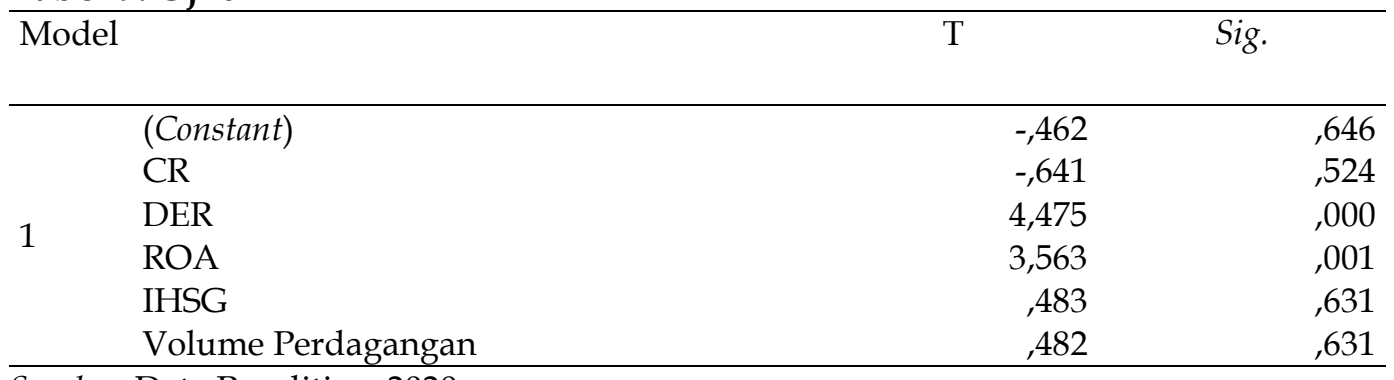

Sumber: Data Penelitian, 2020

Hasil dari penelitian ini menunjukkan bahwa Current Ratio tidak berpengaruh pada harga sahamnya pada perusahaan utilitas dan transportasi yang terdaftar di BEI periode 2016-2019. Hasil penelian ini juga sejalan dengan 
Anah, dkk (2018) yaitu Current Ratio tidak memiliki pengaruh terhadap harga saham pada sub sektor transportasi yang diteliti Tingkat likuiditas yang dilihat dari rasio current yang tinggi belum tentu menandakan perusahaan memiliki kinerja keuangan yang baik disebabkan jika aktiva lancar tidak produktif maka akan mengganggu kelancaran aktivitas perusahaan juga yaitu contohnya kas yang berlebihan dan menganggur, persediaan yang terlalu banyak dan menumpuk serta piutang yang kurang produktif dengan perputaran yang lambat.

Penelitian ini menunjukkan hasil dimana DER berpengaruh positif pada harga saham utilitas dan transportasi yang terdaftar pada BEI periode 2016-2018. Penelitian ini juga sejalan dengan hasil penelitian Samsuar dan Akramunnas (2017) yaitu DER mempunyai pengaruh positif terhadap harga saham. Namun berbeda dengan hasil penelitian (Priliyastuti \& Stella, 2017) yang menunjukkan tidak ada pengaruh DER terhadap harga saham. Pada sektor ini harga saham dipengaruhi oleh penggunaan hutang dikarenakan penggunaan hutang yang cukup tinggi menunjukkan perkembangan perusahaan dalam mengelola usahanya sehingga memberikan kepercayaan kepada investor jika perusahaan memiliki prospek yang baik.

Dari penelitian menunjukkan bahwa ROA berpengaruh positif terhadap harga saham pada perusahaan utilitas dan transportasi yang terdaftar di Bursa Efek Indonesia periode 2016-2019. Hasil penelian sesuai dengan penelitian Samsuar dan Akramunnas (2017) yaitu harga saham dipengaruhi secara positif terhadap oleh ROA. Namun beda dengan hasil penelitian (Amrah \& Elwisam, 2018) yang menemukan tidak adanya pengaruh ROA terhadap harga saham. Perusahaan yang dapat meningkatkan laba sudah tentu mampu bertahan dari kondisi yang sulit dan persaingan global, sehingga jika perusahaan terus menerus mampu meningkatkan laba dari satu periode ke periode berikutnya akan memberikan sinyal positif bagi investor yang berdampak positif terhadap harga saham.

Kesimpulan dari penelitian dapat dilihat bahwa IHSG tidak ada pengaruh pada harga sahamnya perusahaan utilitas dan transportasi yang terdaftar di Bursa Efek Indonesia periode2016-2019. Hasil penelian ini juga sama dengan Samsuar dan Akramunnas (2017) yaitu IHSG tidak mempengaruhi harga saham.IHSG tidak mempengaruhi harga saham dikarenakan Indeks ini merupakan saham gabungan, yang mana jika terjadi perubahan pada IHSG belum tentu akan mempengaruhi harganya karena investor akan mengamati faktor internal dari perusahaan tersebut terlebih dahulu.

Penelitian ini dapat disimpulkan volume dagang tidak mempengaruhi harga sahamnya perusahaan utilitas dan transportasi yang terdaftar di Bursa Efek Indonesia periode 2016-2019. Penelian ini berbeda dengan hasil dari penelitian Abidin, dkk (2016) dimana menunjukkan volume dagang berpengaruh terhadap harga saham. Frekuensi dagang tinggi belum tentu menunjukkan saham perusahaan tersebut banyak diminati oleh investor, dikarenakan jika semakin meningkatnya volume perdagangan ditakutkan harga saham akan menurun seiring dengan banyaknya permintaan sehingga volume perdagangan tidak dapat dijadikan indikator dalam menilai harga saham suatu perusahaan 


\section{SIMPULAN}

Hasil uji pada penelitian yang dilakukan kali ini dapat disimpulkan bahwa, Harga saham pada perusahaan sektor utilitas dan transportasi yang terdaftar di Bursa Efek Indonesia 2016-2019 dipengaruhi dari DER dan ROA. Sedangkan CR, Indeks Harga Saham gabungan, dan Volume perdagangan tidak mempengaruhi Harga saham. Tetapi CR, DER,ROA, Indeks Harga Saham Gabungan, volume perdagangan secara serentak mempengaruhi Harga Saham pada sektor ini.

Adapun keterbatasan pada penelitian ini adalah pada sektor yang diteliti sebanyak $73,92 \%$ dari populasi yang tidak dapat dijadikan sampel karena tidak menghasilkan laba, sehingga pada penelitian selanjutnya disarankan untuk meneliti pada sektor yang memiliki sampel minimal $80 \%$ dari populasi.

Para investor, disarankan agar tidak hanya melakukan analisis faktor internal perusahaan saja tetapi juga harus memperhatikan faktor eksternal perusahaan yang mempengaruhi harga saham misalnya suku bunga, inflasi dan jumlah uang beredar.Pada sektor ini, disarankan untuk lebih meningkatkan performance keuangannya dengan meningkatkan penggunaan asetnya.

\section{REFERENSI}

Alam, S., Miah, M. R., \& Karim, M. A. (2016). Analysis on Factors that Affect Stock Prices: A Study on Listed Cement Companies at Dhaka Stock Exchange. Research Journal of Finance and Accounting, Vol 7(No 18), ISSN 2222-2847.

http://iiste.org/Journals/index.php/RJFA/article/viewFile/33297/34195

Alipudin, A., \& Oktaviani, R. (2016). Pengaruh Eps, Roe, Roa Dan Der Terhadap Harga Saham Pada Perusahaan Sub Sektor Semen Yang Terdaftar Di Bei. JIAFE (Jurnal Ilmiah Akuntansi Fakultas Ekonomi), 2(1), 1-22. https://doi.org/10.34204/jiafe.v2i1.521

Amrah, R. Y., \& Elwisam. (2018). Pengaruh Current Ratio, Return on Assets, Debt To Equity Ratio Dan Total Assets Turnover Terhadap Harga Saham Pada Perusahaan Lq45 Tahun 2013-2015. Jurnal Ilmu Manajemen Oikonomia, 14(1), 46-62.

Arifannisa, W., \& Nugraha, A. A. (2017). Pengaruh Faktor-Faktor Fundamental dan Faktor-Faktor Teknikal Terhadap Harga Saham (Studi Empiris pada Perusahaan Manufaktur Sektor Industri Barang Konsumsi yang Terdaftar di Bursa Efek Indonesia Periode 2013-2015). 298-309.

Astuty, P. (2017). The influence of fundamental factors and systematic risk to stock prices on companies listed in the Indonesian stock exchange. European Research Studies Journal, 20(4), 230-240. https://doi.org/10.35808/ersj/830

Baresa, S., Bogdan, S., \& Ivanovic, Z. (2013). Strategy Of Stock Valuation By Fundamental Analysis. STRATEGY OF STOCK VALUATION BY FUNDAMENTAL ANALYSIS, 4(1), 45-51.

Chiah, M., \& Zhong, A. (2020). Trading from home: The impact of COVID-19 on trading volume around the world. Finance Research Letters, 37(September), 101784. https:/ / doi.org/10.1016/j.frl.2020.101784

Fitri, R. R., Hosen, M. N., \& Muhari, S. (2016). Analysis of Factors that Impact Dividend Payout Ratio on Listed Companies at Jakarta Islamic Index. International Journal of Academic Research in Accounting, Finance and 
Management Sciences, 6(2), 87-92. https://doi.org/10.6007/ijarafms/v6i2/2074

Ghobadi, M., \& Abdolbaghi, A. (2014). Profitability Of Technical Analysis Indicators To Earn Abnormal Returns In International Exchange Markets. International Scientific Journal Theoritical \& Applied Science, 19(11), 20-26. https://doi.org/http://dx.doi.org/10.15863/TAS.2014.11.19.5

Gibson, C. H. (2009). Financial Reporting $\mathcal{E}$ Analysis (J. W. Calhoun, Ed.; 11th ed.). South-Western Cengage Learning.

Harsono, A. R., \& Wonokinasih, S. (2018). Pengaruh Inflasi, Suku Bunga, Dan Nilai Tukar Rupiah Terhadap INdeks Harga Saham Gabungan (Studi pada Bursa Efek Indonesia Periode 2013-2017). Jurnal Administrasi Bisnis, 60(2), 102-110.

Ilmiyono, A. F. (2019). The Effect of ROE, ROA and EPS toward Stock Prices in Companie sub Sektor Construction and Buildings Listed in Exchange Indonesia Effect ( IDX ). International Journal of Latest Engineering and Management Research (IJLEMR), 04(08), 24-35.

Jusuf, J. (2016). Analisis Kredit untuk Account Officer. PT. Gramedia Pustaka Utama.

Komala, L. A. P., \& Nugroho, P. I. (2013). The Effects of Profitability Ratio, Liquidity, and Debt towards Investment Return. Journal of Business and Economics, 4(11), 1176-1186. http:/ / www.academicstar.us

Moein Aldin, M., Dehghan Dehnavi, H., \& Entezari, S. (2012). Evaluating the Employment of Technical Indicators in Predicting Stock Price Index Variations Using Artificial Neural Networks (Case Study: Tehran Stock Exchange). International Journal of Business and Management, 7(15), 25-34. https://doi.org/10.5539/ijbm.v7n15p25

Nasution, Z. L., Sulistyo, \& Halim, A. (2016). Pengaruh Volume Perdagangan Saham, Frekuensi Perdagangan Saham, Volatilitas Harga Saham, Dan Kapitalsiasi Pasar Terhadap Return Saham Perusahaan Makananan Dan Minuman Yang Terdaftar Di Bursa Efek Indonesia. Journal Riset Mahasiswa, $4(2), 1-28$.

Priliyastuti, N., \& Stella, S. (2017). Pengaruh Current Ratio, Debt To Asset, Debt To Equity, Return on Assets dan Price Earnings Ratio terhadap Harga Saham. Jurnal Bisnis Dan Akuntansi, 19(5), 320-324.

Purnamawati, I. G. A. (2016). The effect of capital structure and profitability on stock price (Study of the manufacturing sector in Indonesia Stock Exchange). International Journal of Business, Economics and Law, 9(1), 10-16. https://www.ijbel.com/wp-content/uploads/2016/05/K9_52.pdf

Rambe, H. M. F., Gunawan, A., Julita, Parlindungan, R., \& Gultom, D. K. (2015). Manajemen Keuangan. Citapustaka Media.

Rehman, M. Z., Khan, M. N., \& Khokhar, I. (2015). Investigating LiquidityProfitability Relationship : Evidence from Companies Listed in Saudi Stock Exchange (Tadawul). Journal of Applied Finance E Banking, 5(3), 159-173.

Samsuar, T., \& Akramunnas. (2017). Pengaruh Faktor Fundamental Dan Teknikal Terhadap Harga Saham Industri Perhotelan Yang Terdaftar Di Bursa Efek Indonesia. Jurnal Ekonomi, Keuangan Dan Perbankan Syariah, 1(1), 116-131. http://library1.nida.ac.th/termpaper6/sd/2554/19755.pdf 
Sudana, I. M. (2015). Manajemen Keuangan Perusahaan : Teori E Praktik. Erlangga. Sunday, \& Small, S. (2012). Liquidity Management and Corporate Profitability: Case Study of Selected Manufacturing Companies Listed on the Nigerian Stock Exchange. Business Management Dynamics, 2(2), 10-25. www.bmdynamics.com

Suresh, M. R. (2013). A Study on Fundamental and Technical Analysis. International Journal of Marketing, Financial Services \& Management Research, 2(5), 44-59. www.indianresearchjournals.com

Thapa, K. B. (2019). Influencing Factors of Stock Price in Nepal. NCC Journal, 4(1), 113-120. https:/ / doi.org/10.3126/nccj.v4i1.24744 